Article

\title{
For Farmers or the Environment? The European Parliament in the 2013 CAP Reform
}

\author{
Viviane Gravey ${ }^{1, *}$ and Aron Buzogány ${ }^{2}$ \\ ${ }^{1}$ School of History, Anthropology, Philosophy and Politics, Queen's University Belfast, UK; E-Mail: v.gravey@qub.ac.uk \\ 2 Institute of Forest, Environmental and Natural Resource Policy, University of Natural Resources and Life Sciences, Austria; \\ E-Mail: aron.buzogany@boku.ac.at \\ * Corresponding author
}

Submitted: 20 January 2021 | Accepted: 26 May 2021 | Published: 30 July 2021

\begin{abstract}
The Common Agricultural Policy (CAP) was the last policy field to be placed under the Ordinary Legislative Procedure and its 2013 reform was the first to be decided under this rule. This article analyses how rule changes following the Lisbon Treaty have shaped policy outcomes related to 'greening,' i.e., making agricultural policy more environmentally friendly. Measuring the policy ambitions of amendments during the different phases of the legislative process (the processing phase within the Parliament and the negotiating phase during trilogues), we find that the European Parliament weakened the Commission's greening proposals - but did so to support an alternative greening agenda built on different policy instruments. This means that rule change has altered the power balance between the institutions, making the Commission more dependent on the European Parliament. In the 2013 reform, this new balance of power came at the cost of greening the CAP.
\end{abstract}

\section{Keywords}

Common Agricultural Policy; European Parliament; environment; greening; Lisbon Treaty; policy ambition

\section{Issue}

This article is part of the issue "Resilient Institutions: The Impact of Rule Change on Policy Outputs in European Union Decision-Making Processes" edited by Ariadna Ripoll Servent (University of Salzburg, Austria) and Angela Tacea (Vrije Universiteit Brussel, Belgium).

(C) 2021 by the authors; licensee Cogitatio (Lisbon, Portugal). This article is licensed under a Creative Commons Attribution 4.0 International License (CC BY).

\section{Introduction}

After the Lisbon Treaty, inter-institutional power dynamics of the EU have been marked by two contrary developments: The empowerment of the European Parliament (EP) through the extension of both budgetary and legislative powers and the crisis-induced activism of the EU Council, which was often seen to limit the manoeuvring space available for supranational institutions (Bickerton et al., 2015). While the intra-institutional power dynamics that results from these two contrary developments have attracted much academic interest (see Bressanelli \& Chelotti, 2019; Roederer-Rynning, 2019a), less attention has been given to the policy effects these changes have had. We address this by turning to the EU's largest redistributive policy: the Common Agricultural Policy (CAP), which was under strict intergovernmental control before the rule changes imposed by the Lisbon Treaty. The CAP is the EU's oldest and most expensive policy, representing approximately $40 \%$ of the overall budget (Swinnen \& Knops, 2012). A rich literature discusses the 'exceptionalism' of EU agricultural policy (Daugbjerg \& Feindt, 2017; Roederer-Rynning, 2019b) and agrees that it is marked by "fundamental value disagreement about the purposes and nature of agricultural policy" (Greer \& Hind, 2012, p. 333). This disagreement is particularly marked during major reforms in which both the CAP budget and its instruments can be profoundly changed (Daugbjerg \& Swinbank, 2011).

This article investigates the 2013 reform of the CAP where the EP acted as co-legislator for the first time. As the last policy domain to be placed under co-decision 
after decades of an 'exceptionalist' policy regime characterised by intergovernmental consensus, the CAP is a particularly hard case for parliamentarisation, which we understand as the increasing role of the EP in EU decisionmaking (see Roederer-Rynning, 2019a). By focusing on environmental ambitions related to the CAP, we consider the impact of rule change, in this case parliamentarisation, through the different phases of the 2013 reform's life cycle. While the existing literature on CAP reform has mainly focused on inter-institutional development (see, e.g., contributions in Swinnen, 2015) we complement this with a novel assessment of the policy content that allows us to study the reform process in more detail.

Our fine-grained analysis of changes to the three 'greening' policy instruments-the green payment (GP), Cross-Compliance (CC) and agri-environment-climate measures (AECM) - contributes to two on-going debates about the EP's autonomy as a full-fledged co-legislator and its policy ambitions. The first debate concerns whether the EP is able to exercise its new-found powers as well as the effects of intra-institutional dynamics following the Lisbon Treaty and the serial crises that occurred in the decade that followed (Bressanelli \& Chelotti, 2019; Roederer-Rynning, 2019a). Our findings highlight that the EP has become a more important actor which needs to be taken into account in decision-making on the CAP, developing its own distinct policy agenda and favouring different policy instruments than the Council or Commission.

This has consequences for the second debate about whether increased EP powers have weakened its progressive credentials (Alons, 2017; Burns et al., 2013, p. 935; Ripoll Servent, 2015). Agricultural policy is an outlier: The EP's Committee on Agriculture and Rural Development (AGRI) has long been a bastion for the status quo, as reluctant, if not more, than the Council on CAP reform. This is in sharp contrast with issues such as data protection or the environment, where the EP had long been more radical than the Council yet tempered its radicalism when gaining greater power (Burns, 2019; Ripoll Servent, 2015). This created a dilemma for the EP Plenary: Would it endorse AGRI's position despite its lack of representativeness, or would it risk undermining its standing as 'responsible' and 'reasonable' in its first CAP reform as a co-legislator by rejecting its Committee's position? We find that the Plenary attempted to reject the Committee's position on the flagship GPs but failed due to polarisation, while it was able to adopt more ambitious positions than AGRI on the other two instruments.

The next section introduces the theoretical expectations found in the literature concerning the effects of rule change on intra-institutional (within the EP), inter-institutional (between Commission, EP and Council) and sectoral dynamics (agriculture specific). Section 3 provides background information for CAP-related policy making before the 2013 reform. Section 4 details our empirical approach on how the legislative amendments were analysed. The empirical section, Section 5, stud- ies the legislative changes made within the EP, focusing on the policy positions of both AGRI and the Plenary and discusses the outcomes of the 2013 trilogues. This shows that the EP played a key role, together with the Council, in weakening the European Commission's original greening proposals. Yet this should not be read as the EP rejecting further CAP greening (Swinnen, 2015, p. 14). Instead, the EP followed its own alternative greening agenda, focusing on and strengthening other instruments such as voluntary AECMs. We close by highlighting the need for closer coordination between the European Commission and EP in order to unlock more fundamental CAP reforms.

\section{Rule Change in the EP: Intra-Institutional, Inter-Institutional and Sectoral Dynamics}

Rule change in the field of agricultural policy is part of a broader effort to normalise agriculture policy away from exceptionalism. Exceptionalism, i.e., "the special treatment of a sector by governments and international organisations and the belief system that provides cognitive justification and political legitimation" is not just about agriculture policy ideas or interests, but also institutions, and who gets to decide on the CAP (Daugbjerg \& Feindt, 2017, p. 1568). As the EU's only directly elected institution, strengthening the EP holds wide-ranging democratic implications and can affect the content and shape of policies. Parliamentarising the CAP may offer an opportunity for policy change away from the exceptionalist status quo which has long favoured the interests of farmers. Conversely, it may offer an opportunity to re-legitimise an amended status quo, bolstering 'post-exceptionalism,' i.e.:

A less compartmentalised policy arena (institutions and interests) with an updated set of policy ideas that retain at its core claims that a policy sector is special, albeit with updated arguments that relate to the problems on the evolving policy agenda and which trigger novel policy instruments. (Daugbjerg \& Feindt, 2017, p. 1574)

This article analyses whether the strengthened EP can foster, or hinder meaningful CAP reform, i.e., reform which goes further than just providing new justifications to the status quo. We address this question by considering the EP's actions during the first CAP reform under the Ordinary Legislative Procedure, the 2013 reform. We study the respective positions of the Commission, Council and EP (both Plenary and AGRI) on one of the central planks of the 2013 reform: greening. In doing so, the contribution aims to understand how Lisbon Treatyrelated changes in rules have led to shifts in intra- and inter-institutional power dynamics and how these, in turn, affect policy outputs. More concretely, we focus on how a certain rule change (the extension of codecision to agricultural policy), have affected relations between 
i) EP's AGRI committee and the Commission, ii) AGRI and the EP's Plenary, and iii) the EP's Plenary and the Council. Overall, we assess what this rule change means for the possibility of a meaningful CAP reform. Studies of EP legislative organisation usually highlight three perspectives on the role of EP committees (see Yordanova, 2009). From an 'informational' perspective, EP committees serve the Plenary's informational needs. According to the 'partisan' perspective, committees are arenas of party leaders to enhance group cohesion. The 'distributional' perspective underlines the role of committees as serving special interests. The last perspective is often seen to fit the EP's AGRI Committee which has traditionally attracted a large share of representants of farming interests, such as agricultural landholders or members of farmer associations (Roederer-Rynning, 2015). This is not likely to change with the Lisbon Treaty, which placed the policy under codecision. Thus, it remains doubtful whether the EP gaining power would change the course of EU agricultural policy due to AGRI's strong support for the status quo (Knops \& Swinnen, 2015) and the EP's comparative lack of administrative resources (Swinnen \& Knops, 2012). We thus expect the AGRI committee to remain more closely aligned with agricultural interests than the Commission and thus adopt fewer green proposals (H1).

Regarding intra-institutional dynamics within the EP, the literature assumes that despite different national and party lines, the EP will usually favour a high degree of internal cohesion in order to strengthen its position in inter-institutional bargaining (Bressanelli \& Chelotti, 2019 , p. 268). While there are cases of long-standing conflicts between the different committees, such as AGRI and the environment committee (Burns, 2006), conflicts between the Plenary and the committees are mostly seen to be mediated through similar power distribution (Yordanova, 2009), the foresight of expert MEPs steering the policy process in the committees with the whole Plenary in mind (Roger \& Winzen, 2015), and through partisan and national linkages between committee members and their respective party groups (Ringe, 2010). However, there is also evidence that for some EP committees, such as Civil Liberties, an increase in power has tempered their more radical 'liberal' or 'green' positions (Burns, 2019; Ripoll Servent, 2019)—with committees feeling "compelled to behave responsibly-for the 'good' of the Union, or because they were hard-pressed by national leaders" (Bressanelli \& Chelotti, 2019, p 267). But as AGRI defends the status quo and is closely aligned with the Council, the pressure to 'behave responsibly' will be felt particularly by the Plenary, not the committee. Following Swinnen (2015, p. 8), we expect that the Plenary will be more radical than AGRI-and yet, that it will prioritise institutional gains (being seen as responsible) over policy gains (a greener CAP; $\mathrm{H} 2$ ).

Fabbrini (2019) argues that the Lisbon Treaty installed a dual regime of a supranational and an intergovernmental constitution in which the EP has gained an equal say when it comes to regulatory policy under the supranational constitution, but the intergovernmental constitution remains in force for policies that impose high economic and political costs on member states. Agriculture is under the intergovernmental constitution: An area known for 'entrenched intergovernmentalism' where "member-states have always been jealous of their prerogatives" (Roederer-Rynning \& Schimmelfennig, 2012, p. 952). As such, we can expect that the EP is likely to play a 'subordinate role' on CAP reform despite its formally equal institutional power (Fabbrini, 2019, p. 420). This assumption is reinforced by capacity shortcomings and the introduction of trilogues. The Commission and the Council "have built up working relationships since the inception of the CAP" and both have access to a depth of in-house expertise on farm policy and experience of past CAP reforms which the EP lacks (Bureau, 2012, p. 339). Trilogues have also made the EP more responsible through inter-institutional socialisation effects (Ripoll Servent, 2015). Thus, we expect EP to be in a weaker position and for the final text to be closer to Council than EP preferences due to either lack of EP expertise on this issue or unwillingness of the EP to go head-to-head with the Council in an area of high political salience (H3).

\section{Greening the CAP? The 2013 Reform in Context}

The CAP has been reformed multiple times since the early 1960s, but until the 2009 Lisbon Treaty these reforms were agreed between the Commission and the Member States-the EP was only consulted (Greer \& Hind, 2012). In addition to extending the Ordinary Legislative Procedure to agriculture, the Lisbon Treaty changed how the EU's multi-annual financial framework is decided by extending the EP's power to CAP funding. The 2013 Cioloş CAP reform thus saw a major "reshuffling" of the "rules of the game" (Knops \& Swinnen, 2014, p. 13).

Which institutions decide has long been considered central to reform outcomes. For example, Daugbjerg and Swinbank (2007) found that reforms agreed in the European Council (such as the 1999 CAP reform) were less ambitious than reforms agreed in the Council in 1992 and 2003. Within the EP's own system of labour division, AGRI has been mainly in charge of dealing with reforms of the CAP (Greer \& Hind, 2012). AGRI traditionally attracts MEPs with a professional background in agriculture. According to Yordanova (2009, p. 272): "Members with farming group ties [have] a $34.3 \%$ higher probability of joining the Committee on Agriculture and Rural Development" and the committee has been often considered to be an extension of national corporatist relations to the EU-level (Ripoll Servent \& Roederer-Rynning, 2018). Thus, agricultural policy analysts were doubtful as to whether the EP's empowerment would really change the course of EU agricultural policy towards postexceptionalism or even deeper reform due to the strong influence from agricultural interest groups in the AGRI 
committee (Knops \& Swinnen, 2014; Roederer-Rynning, 2015). Our focus in this article is on how rule changes contributed to a different policy outcome by focusing on 'greening' of agricultural policy, a core part of the 2013 reform. Greening the CAP is an old idea which was pushed by environmental NGOs since the early 1990s (Lumbroso \& Gravey, 2013). Over the last 20 years, different policy instruments were developed (Feindt, 2010), aiming either at raising the standard for all European farmers (such as compulsory CC) or at facilitating deeper greening for a minority of farmers (such as voluntary agri-environment measures). While greening has been much discussed in CAP reforms (Erjavec et al., 2015), the degree to which past reforms yielded a paradigm shift toward a more environmentally friendly model of agricultural policy remained unclear (Daugbjerg \& Swinbank, 2011). While policy instruments were often justified on environmental grounds (Feindt, 2010), instruments whose main purpose is environmental represented less than $10 \%$ of the CAP budget by the start of the 2013 reform, while direct payments to farmers were about 70\% (Lumbroso \& Gravey, 2013).

Greening gained particular prominence in the 2013 reform as one of the three buzzwords of the Commission's legislative proposals, alongside capping subsidies and convergence of support levels between the East and the West (Greer \& Hind, 2012). CAP greening, understood as a way to deliver on the idea of 'public money for public goods,' was considered a given in most reform papers produced in 2008-2010 by NGOs, farm lobbies or national governments (Gravey, 2011). This impression became further strengthened by the parallel negotiations on CAP reform and the next multi-annual financial framework which were leveraged by pro-reform actors to demand further greening (Knops \& Swinnen, 2014, pp. 83-84). The Commission tried to establish a quid pro quo between greening and maintaining a sizable budget for the CAP (Matthews, 2013b). But whereas greening as an idea remained a core concept, scholars of EU agricultural policy have argued that greening was used merely to "legitimize the continuation of farm support" (Daugbjerg \& Swinbank, 2016, p. 275) and that the proposals were subsequently watered-down (Alons, 2017; Knops \& Swinnen, 2014).

\section{Empirical Approach}

We analyse this "gradual erosion of the Commission's proposal" (Matthews, 2013b, p. 5) by coding amendments to all three greening policy instruments on a novel greening scale which we adapt from Schaffrin et al. (2015) and Gravey and Jordan (2016). Our focus is on the two central phases of the legislative process: the 'processing phase' within the EP and the subsequent 'negotiating phase' between the three institutions (Knops \& Swinnen, 2014). The processing phase, from October 2011 to April 2013, saw the EP debate on the proposals, decide on which Committees should work on the files and agree on its negotiating mandate in preparation for the trilogues. The negotiating phase, from April to September 2013, saw 50 trilogues between the three institutions, with a key political agreement obtained in June, at the end of the Irish Council Presidency (Knops \& Swinnen, 2014, p. 31).

Our analysis is based on information about the origin, content and success of legislative amendments related to the 2013 reform. Origin and success are common in large-scale amendment analysis (Fertő \& Kovács, 2015). But while this type of analysis draws a picture of the respective bargaining success of the three institutions, it remains silent on the content of policy change. In our case, analysing the content of amendments allows us to assess which amendments were in favour of more environmentally ambitious policy and to reflect the multidimensionality of policy change.

To analyse the content of the amendments, a novel coding scheme was developed which combines the multidimensional characteristics of the Index of Policy Activity by Schaffrin et al. (2015), and the comparative coding of different policy stages adapted from Gravey and Jordan (2016). Schaffrin et al.'s (2015) Index contains six policy intensity (or ambition) measures, four of which (budget, scope, implementation and objectives) are relevant to this specific case. The remaining two (integration and monitoring) were either not relevant for studying greening amendments, or not relevant for the specific legislative phase of decision-making. Our first stage of coding identified which dimensions of the different policy instruments had been debated during the CAP reform process through an analysis of academic and press coverage of the reform and how these have mapped on the different parts of the index. As shown in Table 1, 14 relevant dimensions were identified-most of which concern the new GPs and its three components (crop diversification, permanent pastures, ecological focus areas, or EFA).

In the second stage of coding, changing positions on these 14 indicators during the legislative process were summarised (see Table 1a, in the Supplementary File) and coded as more or less ambitious in terms of greening based on a thorough review of academic, media and stakeholders' analyses of the debates (notably Hart, 2015; Knops \& Swinnen, 2014; Matthews, 2013a, 2013b). The Commission's proposal was coded as 0 , while amendments were coded on a scale reaching from -3 to 3 with higher scores used for greater ambition. As the GP was a brand-new instrument, we could not compare its ambition with results of the previous 2008 CAP reform. But the two other instruments, $\mathrm{CC}$ and agri-environment schemes, were first introduced in the 1990s and repeatedly reformed since. After a report from the European Court of Auditors (2008) branded CC as too complex to be effective, the Commission reduced the scope of $\mathrm{CC}$ by removing a number of rules (European Court of Auditors, 2016), although it strengthened its water and soil protection components (Matthews, 2013b). As such, the proposed greening ambition for CC in the 2013 reform can 
Table 1. 14 policy indicators of greening ambition in 2013 CAP reform.

\begin{tabular}{lll}
\hline Code & Description & Example \\
\hline GP1 & Overall scope of GP & Whether all farmers are entitled to receive it \\
GP2 & Overall objective of GP & Proportion of overall direct payment envelope devoted to GPs \\
GP3 & Implementation & Whether GPs are compulsory or not \\
GP4 & Scope: crop diversification & Minimum area required \\
GP5 & Objectives: crop diversification & Number of crops required \\
GP6 & Scope: permanent pasture & Type of permanent land use concerned \\
GP7 & Objectives: permanent pasture & Whether this is implemented at the farm or regional/national level \\
GP8 & Scope: EFA & Minimum area required \\
GP9 & Objectives: EFA & Number of practices allowed to count as EFA \\
AECM1 & Budget: flexibility & Whether rural development funding can be used to supplement direct \\
& & payments \\
AECM2 & Budget: earmarking & Proportion of rural development funds earmarked for environmental action \\
AECM3 & Objectives: double funding & Whether farmers can be paid twice for the same level of environmental \\
& & service \\
CCP1 & Scope: Statutory Mandatory & Number of requirements \\
& Requirement (SMR) & \\
CCP2 & Scope: Good Agricultural and & Number of conditions \\
& Environmental conditions & \\
\hline
\end{tabular}

be understood as being at best equal to, if not lower than, pre-existing CAP 2008 levels. For agri-environment measures, the 2013 reform prioritised climate change (hence their new name, agri-environment-climate measures, AECM) but the Commission proposal opened the door to a severe drop in budget. Not only was the Second Pillar cut more sharply than the First Pillar in the EU budget, but the guaranteed $25 \%$ from the Second Pillar to be spent on AECM was moved to the preamble of the regulation (Matthews, 2013b). Thus, as with CC, our starting point for the 2013 reform (the Commission proposal) has arguably lower greening ambition than the CAP 2008 status quo.

\section{Findings}

Figure 1 summarises the coding of the policy ambition. Each of the three instruments' grading is obtained by averaging the different dimensions of change for the relevant instrument (GP1-9 for GP, AECM 1-3 for AECMs and CCP1-2 for $(C)$. The $x$-axis shows the temporal dimension of the legislative process starting with the Commission proposal. We plot the ambition on the $y$-axis, where higher scores show more, i.e., greener, policy ambition. When considering averages, one instrument decreased in ambition (GP) and two stayed the same (CC, AECM). In what follows we consider each indicator separately through two different phases: The processing phase which focuses on positions formulated within the EP, and the negotiation phase which includes inter-institutional bargaining. We discuss the temporal development of each involved actor's policy ambition and how, out of 14 greening indicators in the 2013 reform, only three indicators increased in ambition during the legislative process, while nine saw reduced ambition.

\subsection{The Processing Phase}

Policy proposals do not always fit easily within the remit of a single parliamentary committee. When different committees wish to work on a given proposal, the EP can choose to follow one of two distinct procedures. First, the default procedure foresees the appointment of a lead committee with other committees relegated to the role of opinion-givers. Second, the recent "reinforced or associated cooperation procedure," which allows "more than one committee involved in drafting the Parliament's legislative report," with "personnel from more than one committee...involved in negotiations with the Council" (Burns, 2013, p. 991). Unsurprisingly, the EP's Environment Committee, ENVI, which has a long history of trying to influence agriculture discussions in the EP (Roederer-Rynning, 2003) contested the decision made by the EP's Conference of Presidents to appoint AGRI as lead committee under the default procedure (Knops \& Swinnen, 2014, p. 52). ENVI eventually withdrew its complaint in exchange for the inclusion of ENVI rapporteurs in AGRI shadow rapporteur's meetings (Roederer-Rynning, 2015, p. 336).

Within AGRI, a second key choice was made during the appointment of rapporteurs. These rapporteurs were chosen from the two main political groups within the $E P$, and from three different countries: The Portuguese socio-democrat (S\&D) MEP, Capoulas Santos-a former 


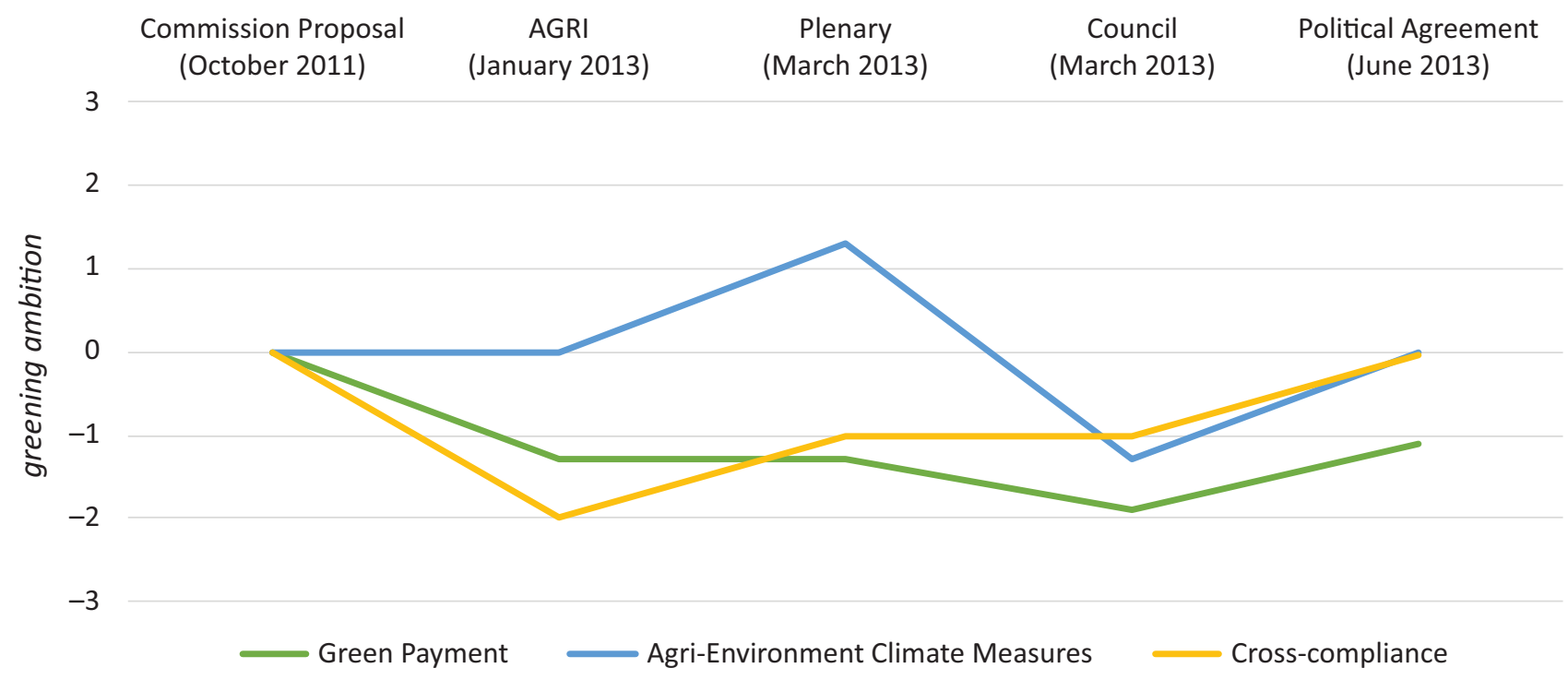

Figure 1. Greening ambition during legislative process compared to Commission proposal (averages). Source: Own coding.

Minister for Agriculture-took charge of the two main regulations for greening (direct payments and rural development) while the French MEP Dantin from the European People's Party (EPP) was in charge of the Single Common Market Organisation regulation and the Italian EPP MEP Giovanni La Via was in charge of the Horizontal Regulation. This choice of rapporteurs by the EP's Grand Coalition effectively side-lined the smaller parties within the Committee. A similar pattern was found in the opinion-giving committees, and in total 16 out of 21 rapporteurships were shared between EPP (13) and S\&D (3), the large number of rapporteurs being due to the three CAP regulations being negotiated in parallel (Roederer-Rynning, 2015, p. 338).

Tensions between AGRI and other committees resurfaced in January 2013, once AGRI had voted its compromise amendments. The compromise amendments were to be used as a negotiating mandate with the Council, but a new internal procedure (rule 70a, now 74) introduced in 2012 allowed other MEPs to contest this. The committee appointment had been made under this new rule which stipulated that the Committee vote "may receive, if the Committee decides so, the blessing of the full Parliament (the Plenary)" (Knops \& Swinnen, 2014, p. 53). Under pressure from other committees and civil society (Spence, 2013), and the threat to veto the multi-annual financial framework if the Plenary was not offered a chance to vote (Erjavec et al., 2015, p. 237), AGRI had to accept this additional step. This resulted in 350 amendments being tabled within the Plenary.

Due to the decision to obtain Plenary support for the negotiating mandate there are two sets of EP positions which we compare in Table 2. AGRI's position, based on the January 2013 votes on compromise amendments, and the EP's position as whole, reflected in the Plenary vote of March 2013 (Knops \& Swinnen, 2014, p. 56). Table 2 reveals how the EP, both in AGRI and in the Plenary, has systematically weakened the GP. Seven out of nine indicators see worsened ambition in the EP and only one remained the same (GP2, on compulsory payments). The only change towards further greening was made in the Permanent Pasture instrument (GP6), where the scope was broadened due to AGRI's compromise amendments in January 2013. However, while AGRI amendments supported a greater scope, they supported weaker objectives (GP7): The rule was to be applied at

Table 2. Comparison of AGRI and Plenary greening ambition.

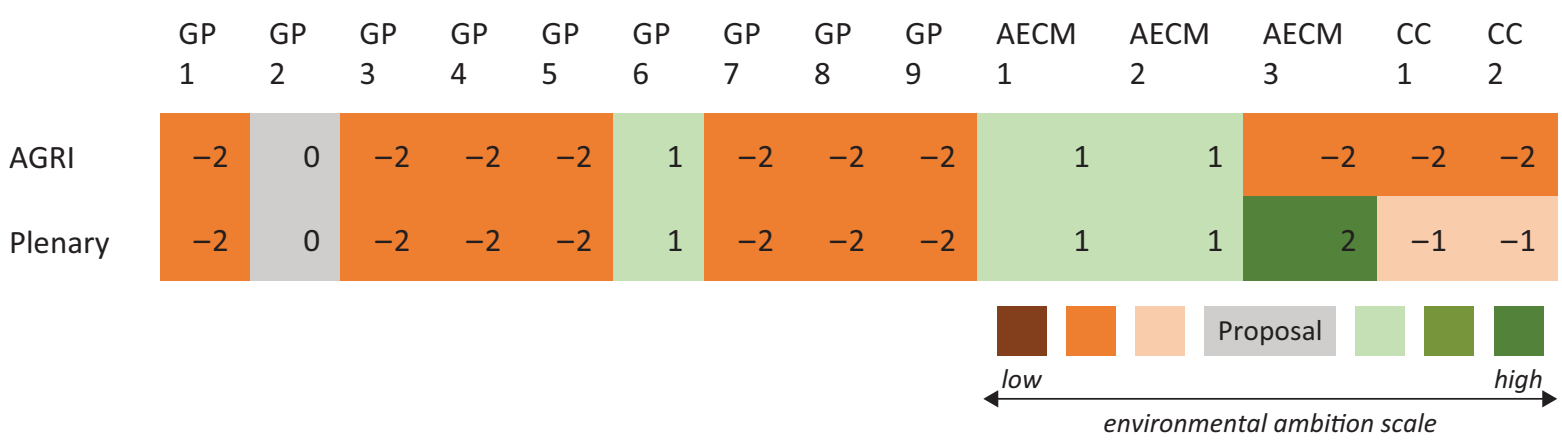

Source: Own coding. 
national, regional or sub-regional level instead of the more constraining farm-level.

This apparent consensus between Plenary and AGRI masks profound controversies surrounding the GP. AGRI's changes to the GP scope (GP1) were highly controversial, as environmental NGOs argued that about $90 \%$ of European farmers would not have to change their practices following the new regulation (Brunner \& Robijns, 2014). But intense political divisions within the Plenary meant that no Plenary amendments succeeded, with different political parties each presenting their own version and voting down any other versions by default. This preserved AGRI's compromise amendments (Knops \& Swinnen, 2014, p. 86) on 'green by definition.'

While changes to the GP showed both AGRI and the Plenary weakening the Commission's proposal (see top half of Figure 2) and indeed the Plenary 'rubberstamping' AGRI's position (Ripoll Servent \& RoedererRynning, 2018), a different picture emerges when looking at AECMs (see bottom half of Figure 2). Discussions on AECMs and the CAP's second pillar more broadly took place under the shadow of the parallel negotiations on the multi-annual financial agreement. The CAP's second pillar suffered greater cuts than the first pillar in the multi-annual financial agreement for 2014-2020: 18\%, compared with a $13 \%$ cut for the first pillar (Little et al., 2013, p. 64).

The outcome of this financial agreement was thus to increase the share of income support in the overall CAPa step back from CAP reforms since 1992 which had steadily increased the share of Rural Development and instruments such as AECMs (Lumbroso \& Gravey, 2013). Concerning AECM, AGRI supported greening amendments in two out of three dimensions (AECM 1 and 2), opposing reverse flexibility, which would see Member States take funding away from the more 'multifunctional' Pillar II to support the more 'productivist' direct payments under Pillar I (Erjavec et al., 2015). As expected, the Plenary moved against AGRI to oppose double funding (Knops \& Swinnen, 2014). This meant all three debated dimensions of AECMs were made more ambitious within the EP.

Finally, concerning CC, AGRI made severe cuts to its scope in its January 2013 vote. These cuts are especially

\section{Green Payment}

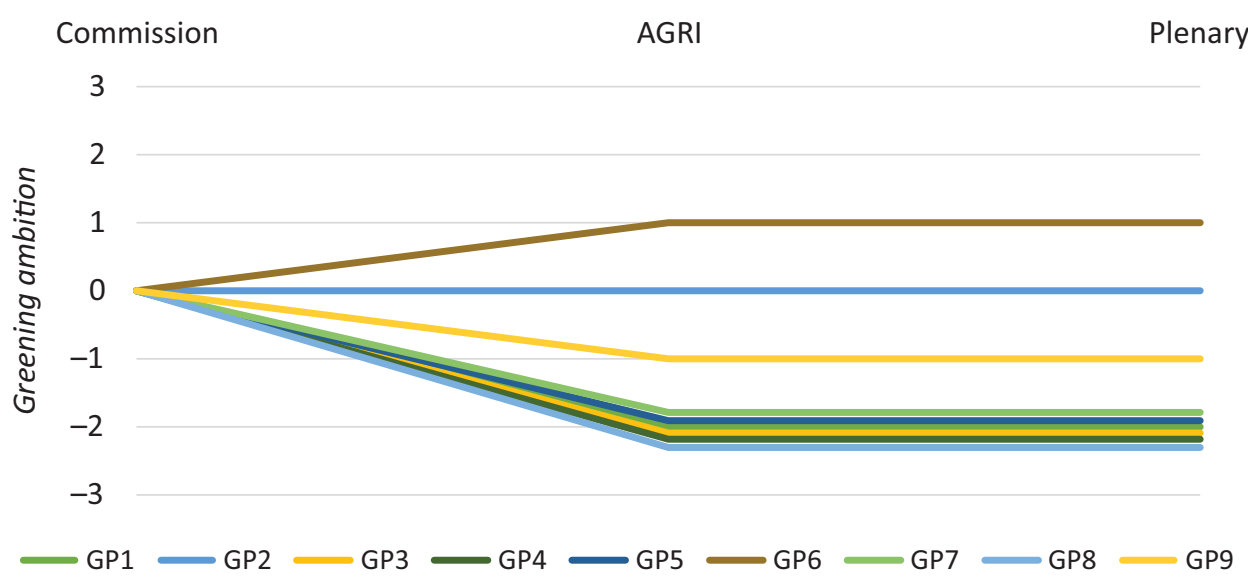

AECMs and Cross-Compliance

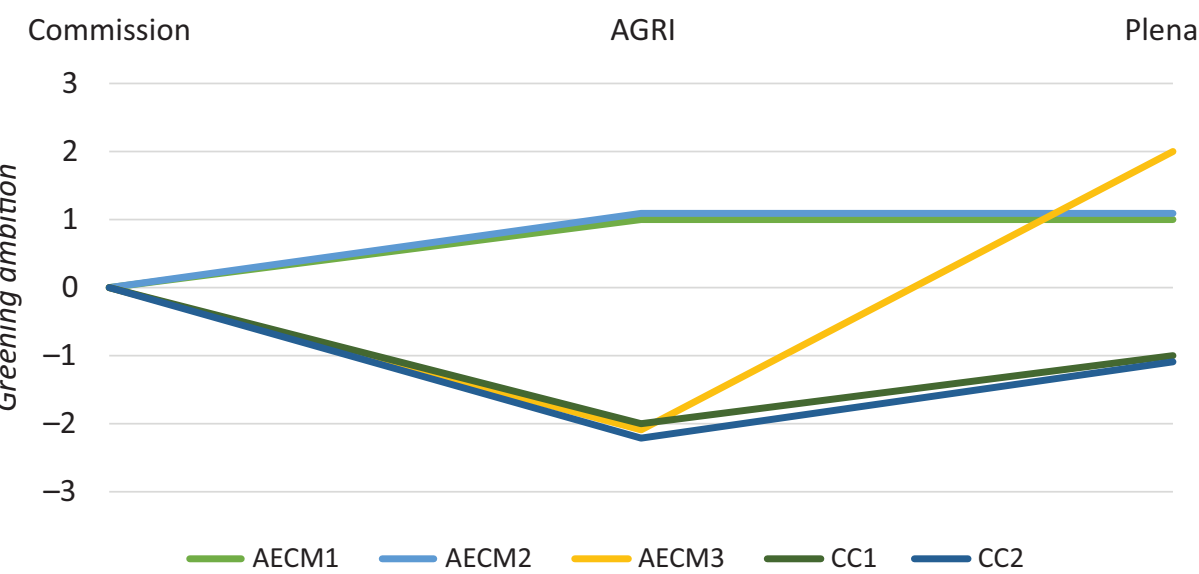

Figure 2. Changes to greening ambition during the processing phase: Comparing GP, CC and AECM (14 indicators). Source: Own coding. 
striking as they went much further than those suggested by the Rapporteur, MEP Giovanni La Via (2012). They further show deep divisions within AGRI, as its compromise amendments propose both cutting seven statutory mandatory requirements and being more ambitious than the Commission by reinstating a number of articles of the Birds and Habitats directives (EP, 2013, amendments 182-183). These cuts were then partially overturned by the Plenary.

In conclusion, while the Plenary voted against AGRI on a few issues - such as double funding, and radical cuts to CC-it did not disavow its Committee and supported most of its negotiation mandate. When focusing on the flagship GPs this confirms the perception of AGRI as a pro-status quo actor $(\mathrm{H} 1)$. It casts doubts on the Plenary's ability to keep its Committees in check $\left(\mathrm{H}_{2}\right)$; polarisation, not calls for 'responsibility,' prevented the Plenary from adopting an alternative position. Once we take into account AECMs and CC, we see both the Plenary and AGRI developing their own alternative greening agenda $(\mathrm{H} 3)$, with a strengthening of AECMs and reluctance towards CC. For these two less-politicised instruments, the Plenary managed to either support AGRI's greater ambition, or improve on AGRI's position.

\subsection{The Negotiating Phase}

Once the EP had adopted its negotiating mandate, the negotiating phase began - an intense succession of 50 trilogue meetings between April and September 2013 (Knops \& Swinnen, 2014), with a key political agreement obtained at the end of the Irish Council Presidency in June 2013. Knops and Swinnen (2014, p. 88) contend that "on most issues, both the EP and the Council proposed less stringent environmental requirements than the EC, but the Council (and Heads of State) went further than the EP in differing from the Commission proposals." While both co-legislators tended to put forward amendments weakening the European Commission's greening plans, they followed different approaches.
Hence, the Council favoured the option to keep the GP mandatory and agreed that penalties for noncompliance with greening requirements could go beyond the greening payment itself (Council of the EU, 2013b, p. 9)-supporting thus a stricter approach than the EP (Table 3, GP3). This is the only indicator where the Council was more ambitious than the Plenary, and as ambitious as the Commission. The Council's main approach to changing the GP was to increase the number of 'equivalent practices' allowed to meet the conditions for receiving greening payments, and to make it easier for farmers to meet the Commission's original three conditions (Council of the EU, 2013a). For example, the Council advocated a menu option of 13 equivalent practices instead of the Commission's five practices for establishing EFAs (Table 3, GP9).

Regarding AECM, the Council focused on funding and flexibility (AECM1, AECM2). Member States have long had the possibility to move a share of their First Pillar funding to the greener Second Pillar (Falconer \& Ward, 2000). But the Council argued that cuts in the overall CAP budget meant that reverse flexibility, from the Second Pillar to the First, should also be possible-up to $15 \%$ of Second Pillar funding for all Member States, increased to $25 \%$ for the 12 Member States with direct payments below $90 \%$ of the EU average (Little et al., 2013, p. 54). Finally, the Council supported the EP's position on CC.

With regard to greening, the trilogues needed to iron out an agreement on six divisive issues. First, on GPs: the level of penalties for non-compliance (GP3), a menu option for EFAs (GP9) and the inclusion of non-grassland in permanent pastures (GP6). Second, on AECM: the possibility for double funding, of earmarking and reverse flexibility (AECM 1-3). Conversely there were no apparent divisions between the co-legislators CC.

On GPs, the Council obtained its menu approach for the EFAs, but with a reduced number of options (10 instead of 13). This should not be seen as a real defeat for the EP as Knops and Swinnen (2014, p. 85)

Table 3. Comparison of Plenary, Council and final agreement greening ambitions.

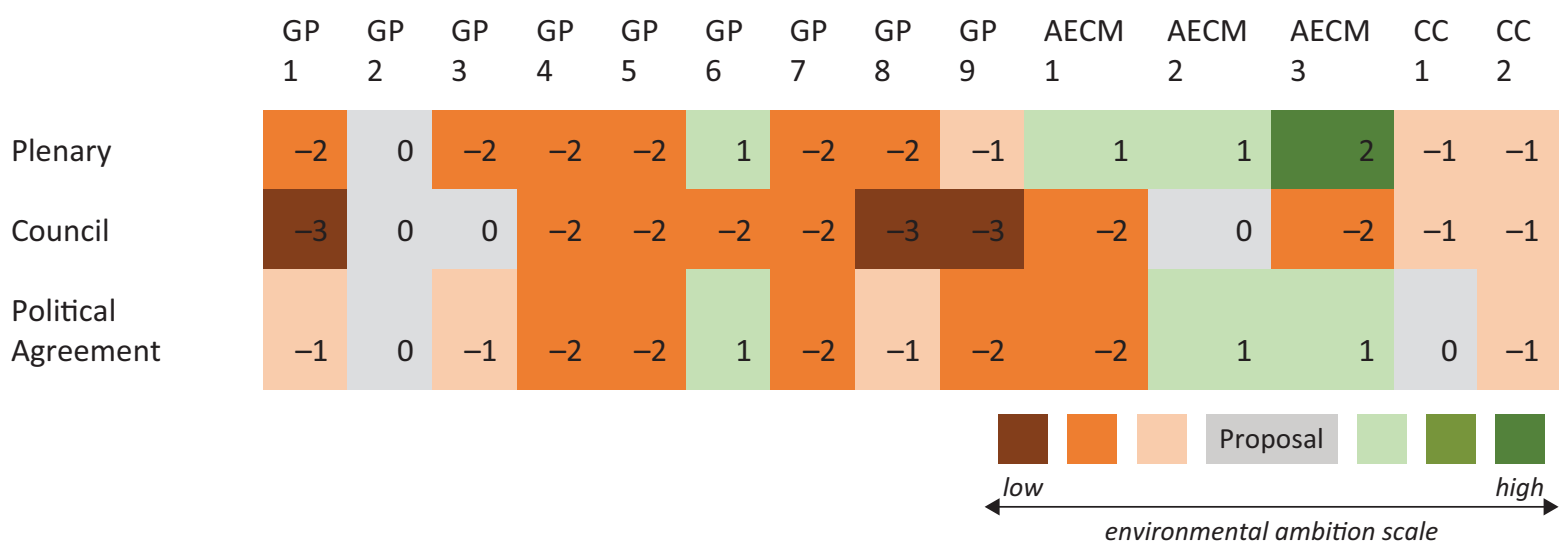

Source: Own coding. 
contend that while the rapporteur MEP Capoulas Santos shied away from including a menu approach in its report "as it would have put the EP in direct opposition to the EC from the very beginning," this approach had great support within the Parliament. The Plenary's proposal for including non-grassland pastures in the permanent pasture element was accepted by the Council. Crucially, the Council's position on penalties-greener than the EP's - was included in the final text. In fact, GP1 (the GP's scope, i.e., which farmers were entitled to the payment and considered green by default) finished slightly more ambitious in the Political Agreement than at the Plenary or Council stage. This could be read as the Commission influencing trilogue discussion-but is more likely due to the reduction in ambition of other dimensions of the GP. Making it much easier for farmers to qualify for GPs (GP4-9) reduced the significance of being exempted from following GP rules. The European Court of Auditors (2017) thus found that $65 \%$ of EU farmers were able to qualify for the GPs without changing how they farmed. On AECM (see Figure 3) both co-legislators gave in to the other's demands: The final text contains earmarking, a much higher level of reverse flexibility as well as rules against double funding.

But what about policy success of the involved institutions? If we compare the final results to the different institution's positions, the EP's success is clear (see Figure 4). In six out of 14 greening indicators, the Plenary's position was included in the final text. In a further five cases, the final outcome was a compromise between the Council and Plenary positions (two), and with Council and Commission (three). Comparatively, the ambition levels of the proposals were only maintained for two out of 14 indicators-demonstrating how thoroughly the co-legislators rewrote the Commission's greening plans. The Council did better than the Commission, but in four out of the five instances where the Council's position was found in the final text, it had previously copied the Plenary's position. Critically, the co-legislators' rewriting of greening saw reduced ambition in nine out of 14 dimensions. But the only three instances in which ambition improved were cases where the Plenary's position (or, for AECM3, a watering down of it) was included in the final text.

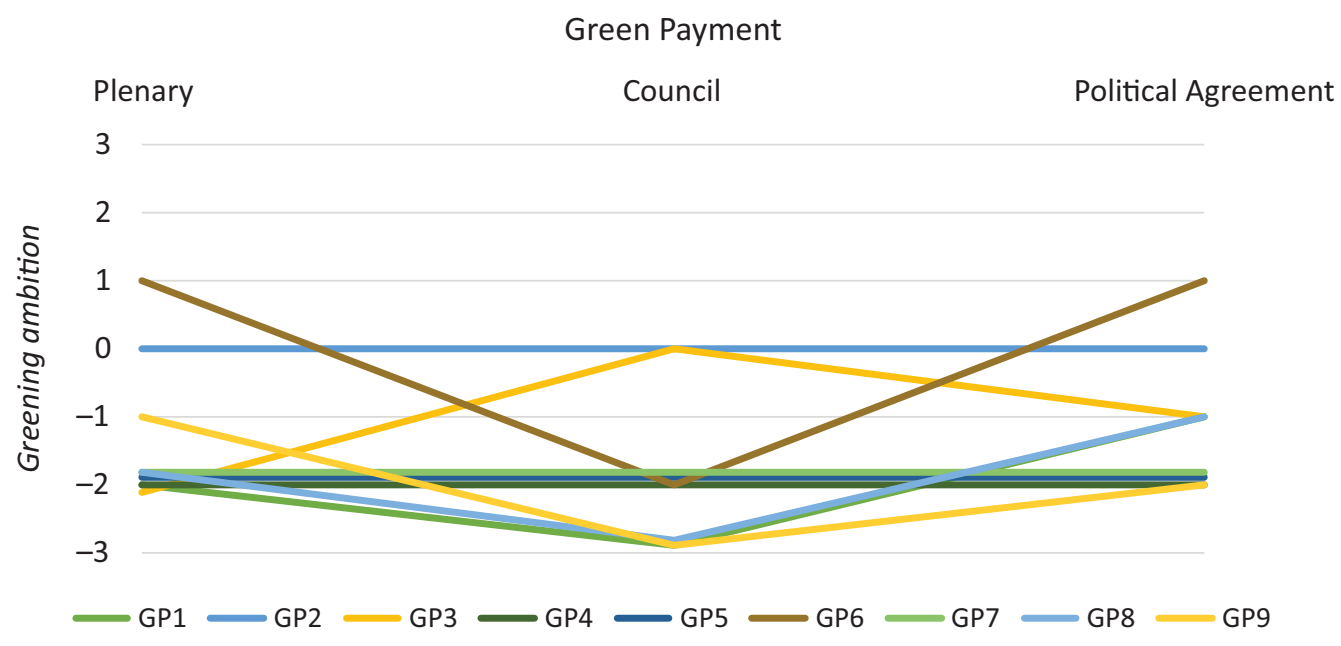

AECMs and Cross-Compliance

Plenary Council Political Agreement

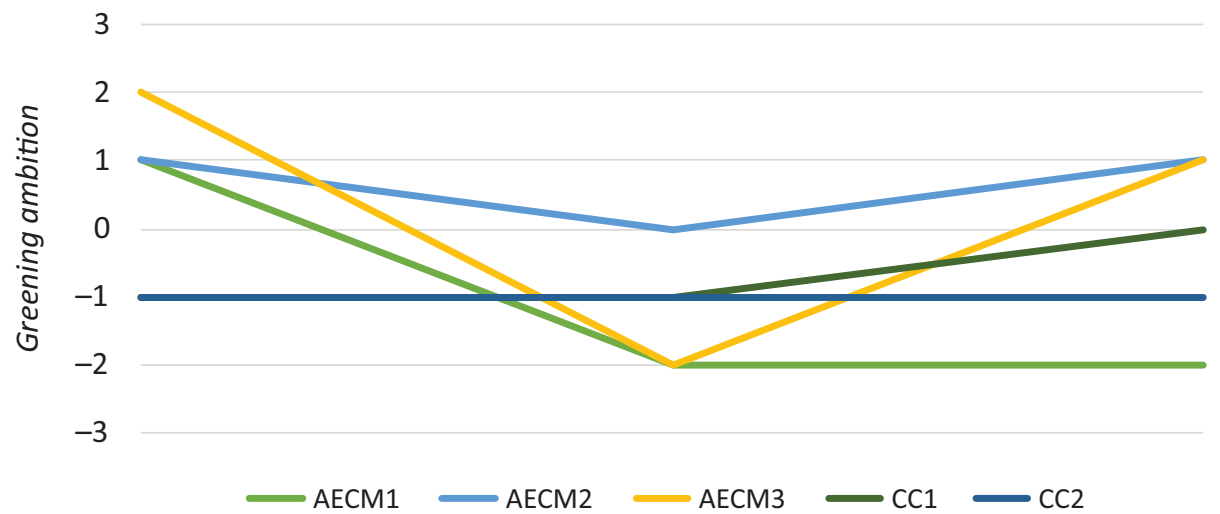

Figure 3. Changes to greening ambition during the negotiating phase: Comparing GP, CC and AECM (14 indicators). Source: Own coding. 


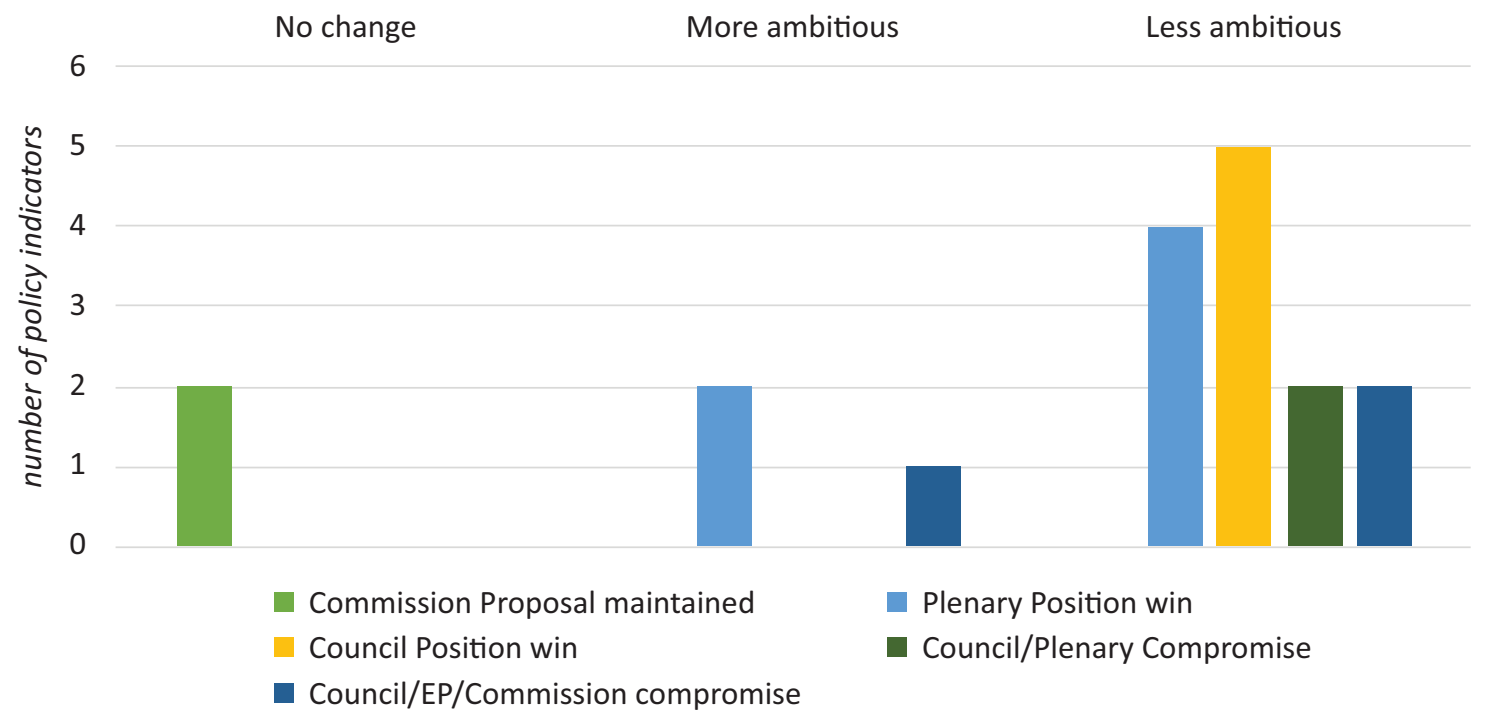

Figure 4. The final agreement in perspective. Source: Own coding.

\section{Conclusions}

The 2013 reform was the first CAP reform under the Ordinary Legislative Procedure. We identified three main obstacles to the EP supporting radical CAP reform. First, the strong alignment between its AGRI committee and conventional farming interest. Second, despite a reputation as a 'green' institution, the Plenary would be reluctant to disavow AGRI and prefers instead a united front ahead of inter-institutional negotiation. Third, lack of expertise and experience, as well as unwillingness to go against Member States' interests in a policy area of high political salience, prevented the EP from developing its own policy alternatives.

We tracked changes made to the three greening policy instruments of the CAP using a coding scheme for policy activity adapted from Schaffrin et al. (2015) and Gravey and Jordan (2016). We categorised the 14 main greening policy proposals debated during this CAP reform. The different institutional positions-European Commission proposals, Council position and two sets of EP's amendments-were then coded for environmental ambition relative to one another for each of these issues.

Comparing the three greening policy instruments using this policy activity index reveals the profound changes made to the Commission proposals. Both the GP and CC proposals were weakened during the legislative process-echoing concerns in the literature about the lack of environmental ambition of the 2013 reform (e.g., Alons, 2017; Knops \& Swinnen, 2014). But the diverging fates of the three instruments confirms the need to look beyond flagship measures such as the GP to evaluate the CAP's environmental ambition. $\mathrm{H} 1$ is overall confirmed in that AGRI overwhelmingly weakened all three instruments (only three out of 14 indicators improved). $\mathrm{H} 2$ is not confirmed. While the Plenary followed AGRI on the GP, it did so by default due to polarisation between political groups, with no alternative amendments suc- ceeding. Furthermore, it diverged on CC and AECMs. This shows that there is no uniform policy-specific pattern of committee-plenary conflict in the EP but variation is contingent on both politics and policy design. Our case shows that the Plenary failed to keep its committee in check on an instrument that was both new and highly politicised-but managed to do so on pre-existing instruments which were less politicised.

This article drew a fine-grained picture of parliamentarisation in the EU by analysing the EP's role as a co-legislator in the 2013 reform. Hence, despite its divisions and its lacking resources, the EP cannot be dismissed either as a simple "status quo influence" (Knops \& Swinnen, 2015, p. 424), or as an automatic ally of the Council-disproving thus $\mathrm{H} 3$. While the EP sided with the Council against the GP, this does not necessarily mean that the EP (both AGRI and the Plenary) are de facto opponents of CAP greening. Nor is the EP an automatic supporter of the Commission. The EP (even pro-environment forces within it) was not convinced of the environmental value of the GPs, nor of the value or need for CC. Instead, the EP-both Plenary and AGRIsupported AECM, and fought successfully to strengthen these elements of the reform. Recent reports from the European Court of Auditors criticising both CC and GPs confirmed that the EP was right to be wary of these instruments (European Court of Auditors, 2016, 2017).

Writing on the EP's green credentials, Burns et al. (2013, p. 952) have argued that "if actors in the EP wish to be successful, they should be assiduous in courting the Commission as the Commission's opinion on EP amendments is crucial." This article has shown that when it comes to greening the CAP, the Commission needs to be more assiduous in courting the EP, convincing the $E P$, most notably the Plenary, not to pursue an alternative greening agenda. The extension of co-decision to the CAP has deeply changed the power balance between the institutions, so that if the Commission is intent on 
further greening the CAP it now needs to change its reform strategy and invest more work to convince the EP of the effectiveness of its proposed policy instruments. The ongoing 2021 reform-proposed under the Juncker Commission, continued under the von der Leyen Commission despite its blatant incoherence with the European Green Deal-shows a similar pattern: The Plenary endorsed AGRI views, and together with the Council weakened the (anyhow limited) environmental ambition of the Commission's proposal. This casts further doubt on the EP's ability to be 'for the environment' when it comes to agriculture-and on the ability of the Commission to keep control of the reform process after the Lisbon rule changes.

\section{Acknowledgments}

The authors would like to thank Charlie Burns and Christilla Roederer-Rynning for comments on an early draft and Mary Dobbs for advice on the last version, Angela Tacea and Ariadna Ripoll-Servent for leading this thematic issue and providing expert feedback as well as the three anonymous reviewers for helpful comments.

\section{Conflict of Interests}

The authors declare no conflict of interests.

\section{Supplementary Material}

Supplementary material for this article is available online in the format provided by the author (unedited).

\section{References}

Alons, G. (2017). Environmental policy integration in the EU's common agricultural policy: Greening or greenwashing? Journal of European Public Policy, 24(11), 1604-1622.

Bickerton, C., Hodson, D., \& Puetter, U. (2015). The new intergovernmentalism: European integration in the post-Maastricht era. Journal of Common Market Studies, 53(4), 703-722.

Bressanelli, E., \& Chelotti, N. (2019). Introduction. Journal of European Integration, 41(3), 265-276.

Brunner, A., \& Robijns, T. (2014). The dubious greening of European agriculture. ICDTS. http://ictsd.org/ i/news/bioresreview/187951

Bureau, C. (2012). Where is the Common Agricultural Policy heading? Intereconomics, 47(6), 316-342.

Burns, C. (2006). Co-decision and inter-committee conflict in the European Parliament post-Amsterdam. Government and Opposition, 41(2), 230-248.

Burns, C. (2013). Consensus and compromise become ordinary but at what cost? A critical analysis of the impact of the changing norms of codecision upon European Parliament committees. Journal of European Public Policy, 20(7), 988-1005.
Burns, C. (2019). In the eye of the storm? The European Parliament, the environment and the EU's crises.' Journal of European Integration, 41(3), 311-327.

Burns, C., Carter, N., Davies, G., \& Worsfold, N. (2013). Still saving the earth? The European Parliament's environmental record. Environmental Politics, 22(6), 935-954.

Council of the EU. (2013a). Proposal for a Regulation of the European Parliament and of the Council establishing rules for direct payments to farmers under support schemes within the framework of the common agricultural policy (CAP Reform)-Presidency consolidated draft Regulation.

Council of the EU. (2013b). Reform of the Common agricultural policy (CAP): Main elements of the Council position. http://www.consilium.europa.eu/uedocs/ cms_data/docs/pressdata/en/agricult/136582.pdf

Daugbjerg, C., \& Feindt, P. H. (2017). Post-exceptionalism in public policy: Transforming food and agricultural policy. Journal of European Public Policy, 24(11), 1565-1584.

Daugbjerg, C., \& Swinbank, A. (2007). The politics of CAP reform: Trade negotiations, institutional settings and blame avoidance. Journal of Common Market Studies, 45(1), 1-22.

Daugbjerg, C., \& Swinbank, A. (2011). Explaining the health check' of the Common Agricultural Policy: Budgetary politics, globalisation and paradigm change revisited. Policy Studies, 32(2), 127-141.

Daugbjerg, C., \& Swinbank, A. (2016). Three decades of policy layering and politically sustainable reform in the European Union's agricultural policy. Governance, 29(2), 265-280.

Erjavec, E., Lovec, M., \& Erjavec, K. (2015). From greening' to greenwash': The drivers and discourses of CAP 2020 reform. In J. F. M. Swinnen (Ed.), The political economy of the 2014-2020 Common Agricultural Policy: An imperfect storm (pp. 215-240). Rowman \& Littlefield.

European Court of Auditors. (2008). Special report No 8/2008: Is cross compliance an effective policy? https://www.eca.europa.eu/en/Pages/Newsltem. aspx?nid=353

European Court of Auditors. (2016). Special report no 26/2016: Making cross-compliance more effective and achieving simplification remains challenging. https://www.eca.europa.eu/en/Pages/Docltem. aspx?did=38185

European Court of Auditors. (2017). Special report no. 21/2017: Greening: A more complex income support scheme, not yet environmentally effective. https://www.eca.europa.eu/en/Pages/Docltem. aspx?did=44179

European Parliament. (2013). Proposal for a decision on the opening of, and mandate for, interinstitutional negotiations (B7-0082/2013). https://www. europarl.europa.eu/doceo/document/B-7-20130082_EN.html 
Fabbrini, S. (2019). Between power and influence: The European parliament in a dual constitutional regime. Journal of European Integration, 41(3), 417-428.

Falconer, K., \& Ward, N. (2000). Using modulation to green the CAP: The UK case. Land Use Policy, 17(4), 269-277.

Feindt, P. H. (2010). Policy-learning and environmental policy integration in the Common Agricultural Policy, 1973-2003. Public Administration, 88(2), 296-314.

Fertő, I., \& Kovács, A. (2015). Parliamentary amendments to the legislative proposals of the 2013 CAP reform. In J. F. M. Swinnen (Ed.), The political economy of the 2014-2020 Common Agricultural Policy: An imperfect storm (pp. 379-411). Rowman \& Littlefield.

Gravey, V. (2011). Réformer la PAC pour quoi faire? Cartographie du débat PAC 2013. IDDRI-Idées pour le débat, 11(4), 1-22.

Gravey, V., \& Jordan, A. (2016). Does the European Union have a reverse gear? Policy dismantling in a hyperconsensual polity. Journal of European Public Policy, 23(8), 1180-1198.

Greer, A., \& Hind, T. (2012). Inter-institutional decisionmaking: The case of the Common Agricultural Policy. Policy and Society, 31(4), 331-341.

Hart, K. (2015). The fate of green direct payments in the CAP reform negotiations. In A. Swinbank (Ed.), The political economy of the 2014-2020 common agricultural policy: An imperfect storm (pp. 245-273). Rowman \& Littlefield.

Knops, L., \& Swinnen, J. (2014). The first CAP reform under the ordinary legislative procedure: A political economy perspective. European Parliament.

Knops, L., \& Swinnen, J. (2015). Co-decision and the CAP: An unfinished story insights on the role of the European Parliament in the 2013 reform. In J. F. M. Swinnen (Ed.), The political economy of the 2014-2020 Common Agricultural Policy: An imperfect storm (pp. 413-439). Rowman \& Littlefield.

La Via, G. (2012). Compromise amendments 1-27, Proposal for a Regulation of the European Parliament and of the Council on the financing, management and monitoring of the common agricultural policy. European Parliament.

Little, J., Massot, A., Ragonnaud, G., \& Tropea, F. (2013). European Council conclusions on the multiannual financial framework 2014-2020 and the CAP. European Parliament Directorate General for Internal Policies.

Lumbroso, S., \& Gravey, V. (2013). International negotiations and debates: To what extent do they hinder or foster biodiversity integration into the CAP? IDDRI: Study, 13(2), 1-46.

Matthews, A. (2013a). Following the negotiations on the Direct Payments Regulation. CAP Reform. http://capreform.eu/following-the-negotiations-onthe-direct-payments-regulation

Matthews, A. (2013b). Greening CAP payments: A missed opportunity? The Institute of International and European Affairs.

Ringe, N. (2010). Who decides, and how? Preferences, uncertainty, and policy choice in the European Parliament. Oxford University Press.

Ripoll Servent, A. (2015). Institutional and policy change in the European Parliament: Deciding on freedom, security and justice. Palgrave Macmillan.

Ripoll Servent, A. (2019). Failing under the 'shadow of hierarchy': Explaining the role of the European Parliament in the EU's 'asylum crisis,' Journal of European Integration, 41(3), 293-310.

Ripoll Servent, A., \& Roederer-Rynning, C. (2018). The European Parliament: A normal parliament in a polity of a different kind in. Oxford University Press.

Roederer-Rynning, C. (2003). From 'talking shop' to 'working parliament'? The European Parliament and agricultural change. Journal of Common Market Studies, 41(1), 113-135.

Roederer-Rynning, C. (2015). COMAGRI and 'CAP after 2013' reform: In search of a collective sense of purpose. In J. F. M. Swinnen (Ed.), The political economy of the 2014-2020 Common Agricultural Policy: An imperfect storm (pp. 331-356). Rowman \& Littlefield.

Roederer-Rynning, C. (2019a). Passage to bicameralism: Lisbon's ordinary legislative procedure at ten.' Comparative European Politics, 17(6), 957-973.

Roederer-Rynning, C. (2019b). The Common Agricultural Policy: A case of embedded liberalism. Oxford University Press.

Roederer-Rynning, C., \& Schimmelfennig, F. (2012). Bringing codecision to agriculture: A hard case of parliamentarization. Journal of European Public Policy, 19(7), 951-968.

Roger, L., \& Winzen, T. (2015). Party groups and committee negotiations in the European Parliament: Outside attention and the anticipation of plenary conflict. Journal of European Public Policy, 22(3), 391-408.

Schaffrin, A., Sewerin, S., \& Seubert, S. (2015). Toward a comparative measure of climate policy output. Policy Studies Journal, 43(2), 257-282.

Spence, T. (2013). Parliament makes U-turn, allows full vote on CAP reform. Euractiv. http://www.euractiv. com/cap/ag-panel-turn-allows-full-vote-c-news518410

Swinnen, J. F. M. (Ed.). (2015). The political economy of the 2014-2020 Common Agricultural Policy: An imperfect storm. Rowman \& Littlefield.

Swinnen, J. F. M., \& Knops, L. (2012). CAP Reform: Will the European Parliament take the bull by the horns? Archive of European Integration. http://aei.pitt.edu/ 35412

Yordanova, N. (2009). The rationale behind committee assignment in the European parliament: Distributive, informational and partisan perspectives. European Union Politics, 10(2) 253-280. 


\section{COGITATIO}

\section{About the Authors}

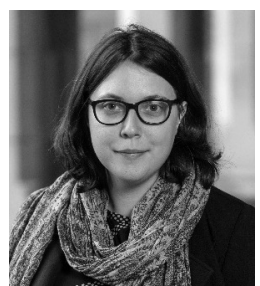

Viviane Gravey is a Lecturer in European Politics at the School of History, Anthropology, Philosophy and Politics at Queen's University Belfast, where she co-chairs the Brexit \& Environment network, investigating the impact of Brexit on the UK and EU environment. She holds a PhD from the University of East Anglia. Her research focuses on the ambition and governance of environmental and agricultural policies in the UK and at EU level.

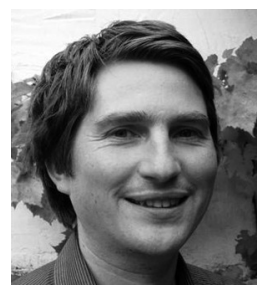

Aron Buzogány works as a Senior Researcher at the Institute of Forest, Environmental and Natural Resource Policy, University of Natural Resources and Life Sciences (BOKU), Vienna, Austria. He holds a PhD from the Free University Berlin and has held academic positions at Free University Berlin, Yale University, the German Public Administration Institute and the University of Munich. His research focuses on comparative politics and policymaking in the EU, with a policy focus on environmental and energy policies. 